\title{
Kinetics and Mechanism of Azidolysis of Y-Substituted Phenyl Benzoates
}

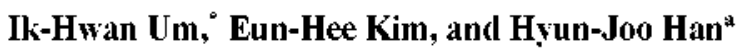 \\ Division of Nano Sciences and Deparment of Chemistrv. Ewha Womans Lmivensitv. Seoul 120-750. Korea \\ "E-mail: ihmmiầewhachr \\ Received November 20.2007
}

\begin{abstract}
Second-order rate constants $\left(k_{\mathrm{N}}\right)$ have been measured spectrophotometrically for reactions of $\mathrm{Y}$-substituted phenyl benzoates (1a-h) with azide ion $\left(\mathrm{N}_{3}^{-}\right)$in $80 \mathrm{~mol} \% \mathrm{H}_{2} \mathrm{O} / 20 \mathrm{~mol} \%$ DMSO at $25.0 \pm 0.1^{\circ} \mathrm{C}$. The Bronstedtype plot for the azidolysis exhibits a downward curvature, i.e., the slope $\left(\beta_{\mathrm{g}}\right)$ changes from -0.97 to -0.20 as the basicity of the leaving group decreases. The $\mathrm{p} K_{\mathrm{a}}^{\circ}$ (defined as the $\mathrm{p} K_{\mathrm{cl}}$ at the center of the Bronsted curvature) is 4.8. which is practically identical to the $\mathrm{pK}_{\mathrm{a}}$ of the conjugate acid of $\mathrm{N}_{3}^{-}$ion (4.73). Hanmett plots correlated with $\sigma$ and $\sigma$ constants exhibit highly scattered points for the azidolysis. On the contrary, the corresponding Yukawa-Tsuno plot results in an excellent linear correlation with $\rho=2.45$ and $\mu=0.40$, indicating that the leaving group departs in the rate-determining step. The curved Bronsted-type plot has been interpreted as a change in the rate-detemining step in a stepwise mechanism. The microscopic rate constants $\left(k_{1}\right.$ and $k_{2} / k_{-1}$ ratio) have been calculated for the azidolysis and found to be consistent with the proposed mechanism.
\end{abstract}

Key Words : Acyl-transfer reaction Azidolysis. Bronsted-type plot. Hammett plot. Yukawa-Tșuno plot

\section{Introduction}

Nucleophilic substitution reactions of carbonyl, ${ }^{1.5}$ sulfon$\mathrm{yl}^{6}$ and phosphyl derivatives ${ }^{7,8}$ have been intensively investigated due to the importance in biological processes as well as in synthetic applications. Reactions of carboxylic esters with neutral nucleophiles (e.g., anines and pyridines) are now finmly understood to proceed through a zwitterionic tetrahedral internediate $T^{ \pm}$with a change in the ratedetermining step (RDS) on the basis of curved Bronstedtype plots found for reactions of esters with a good leaving group. ${ }^{1.5}$ The RDS has generally been suggested to change from breakdown of $\mathrm{T}^{=}$to its formation as the attacking anine becomes more basic than the leaving group by + to 5 p $K_{\mathrm{a}}$ units. ${ }^{1 \cdot 5}$

However, reactions with anionic nucleophiles (e.g., $\mathrm{OH}^{-}$ and aryloxides) have not been clearly understood. In a series of inportant studies. Williams and coworkers have concluded that reactions of 4-nitrophenyl acetate with substituted phenoxides proceed through a concerted mechanism. "The evidence consisted mainly of the absence of a break or curvature in the Bronsted-type plot when the $\mathrm{p} K_{\mathrm{a}}$ of the aryloxides corresponded to that of the leaving t-nitrophenoxide. ${ }^{9}$ The concerted mechanism has further been supported through structure-reactivity conrelations reported by Jencks, ${ }^{\text {li }}$ Rossi, ${ }^{11}$ and Castro, ${ }^{12}$ as well as the study of kinetic isotope effect by Hengge ${ }^{13}$ and Marcus analysis by Guthrie. ${ }^{14}$

On the contrary, Buncel et al. have concluded that acyltransfer to aryloxides occurs through a stepwise mechanism with formation of an addition intermediate being the RDS on the basis of Hanmett plots exhibiting rather poor correlation with $\sigma^{-}$constants but better correlation with $\sigma^{\circ}$ constants. ${ }^{15}$ A similar result has been reported for reactions of aryl

aPresent address: Advanced PKG Development Central R \& D Institute. Samsung Electro-Mechanics. Suwon. Gyunggi 4+3-743. Korea diphenylphosphinates with $\mathrm{OH}^{-}$and for those of aryl dimethylphosphinates with ethoxide ion. ${ }^{16.17}$ Furthemore, we have presented the first spectroscopic evidence, along with kinetic evidence, for an addition intermediate in the reaction of a cyclic sulfinate ester with sodium ethoxide in anliydrous ethanol. ${ }^{18}$

We have recently performed nucleophilic substitution reactions of aryl benzoates and thionobenzoates with $\mathrm{OH}^{-}$ and $\mathrm{CN}^{-}$ions and reported that the reactions proceed through a stepwise mechanism. ${ }^{19}$ We have extended our study to reactions of Y-substituted phenyl benzoates (1a-h) with $\mathrm{N}_{3}{ }^{-}$ion to get further information on the reaction mechanism involving anionic nucleophiles.

\section{Results and Discussion}

Reactions of 1a-h with $\mathrm{N}_{3}^{-}$ion proceeded with quantitative liberation of Y-substituted phenoxide ion and/or its conjugate acid. The kinetic study was performed under pseudo-first-order conditions. e.g. the $\mathrm{N}_{2}{ }^{-}$ion concentration in excess over the substrate concentration. All the reactions obeyed first-order kinetics. Pseudo-first-order rate constants ( $\left.k_{\text {obsd }}\right)$ were calculated from the equation $\ln \left(A_{\times}-A_{l}\right)=-k_{\text {otoil }}$ $t+C$. The plots of $k_{\text {otesd }} v s . \mathrm{N}_{3}{ }^{-}$ion concentration are linear. Thus. the apparent second-order rate constants $\left(k_{\kappa}\right)$ were determined from the slope of the linear plots of $k_{\text {obsit }} v \mathrm{~N}_{3}^{-}$. and summarized in Table 1.

Bronsted-type Correlation. Table 1 shows that the apparent second-order rate constant $\left(k_{\mathrm{K}}\right)$ is significantly dependent on the leaving group basicity, e.g. the $k_{\mathrm{N}}$ value decreases from $0.224 \mathrm{M}^{-1} \mathrm{~s}^{-1}$ to $2.34 \times 10^{-3}$ and $6.42 \times 10^{-5}$ $\mathrm{M}^{-1} \mathrm{~s}^{-1}$ as the $\mathrm{p} K_{4}$ of the conjugate acid of the leaving aryloxide increases from 4.11 to 7.14 and 8.98 . respectively.

The effect of leaving group basicity on reactivity is illustrated in Figure 1. Esters with 2.4-dinitrophenoxide as a 
Table 1. Sumnary of Apparent Second-order and Microscopic Rate Constants tor Reactions of Y-Substituted Phenyl Benzoates (1a-h) with $\mathrm{N}_{3}^{-}$in $20 \mathrm{~mol} \%$ DMSO$/ 80 \mathrm{~mol} \% \mathrm{H}_{2} \mathrm{O}$ at $25.0 \pm 0.1$ ic

\begin{tabular}{|c|c|c|c|c|}
\hline Y & $\begin{array}{c}\mathrm{pK}_{\mathrm{a}} \\
(\mathrm{Y}-\mathrm{PhOH})\end{array}$ & $10^{3} k_{\mathrm{N}} / \mathrm{M}^{-1} \mathrm{~s}^{-1}$ & $10^{3} k_{1} / \mathrm{M}^{-1} \mathrm{~s}^{-1}$ & $10^{2} k_{2} / k_{-1}$ \\
\hline $1 \mathbf{a}, 2,4-\left(\mathrm{NO}_{2}\right)_{2}$ & 4.11 & $224 \pm 3$ & 383 & 340 \\
\hline $1 b, 3,4-\left(\mathrm{NO}_{2}\right)_{2}$ & 5.42 & $124 \pm 11$ & 496 & 33.3 \\
\hline $1 \mathrm{c}, 4-\mathrm{NO}_{2}$ & 7.14 & $2.34 \pm 0.09$ & 151 & 1.58 \\
\hline $1 \mathrm{~d}, 4-\mathrm{CHO}$ & 7.66 & $0.479 \pm 0.049$ & 76.8 & 0.628 \\
\hline $1 \mathrm{e}, 4-\mathrm{CN}$ & 7.95 & $0.993 \pm 0.062$ & 266 & 0.375 \\
\hline 1f, $4-\mathrm{COCH}_{3}$ & 8.05 & $0.232 \pm 0.040$ & 74.0 & 0.314 \\
\hline 1g, 4-COOEt & 8.50 & $0.151 \pm 0.006$ & 107 & 0.142 \\
\hline $1 \mathbf{h}, 3-\mathrm{CHO}$ & 8.98 & $0.064 \pm 0.012$ & 106 & 0.0605 \\
\hline
\end{tabular}

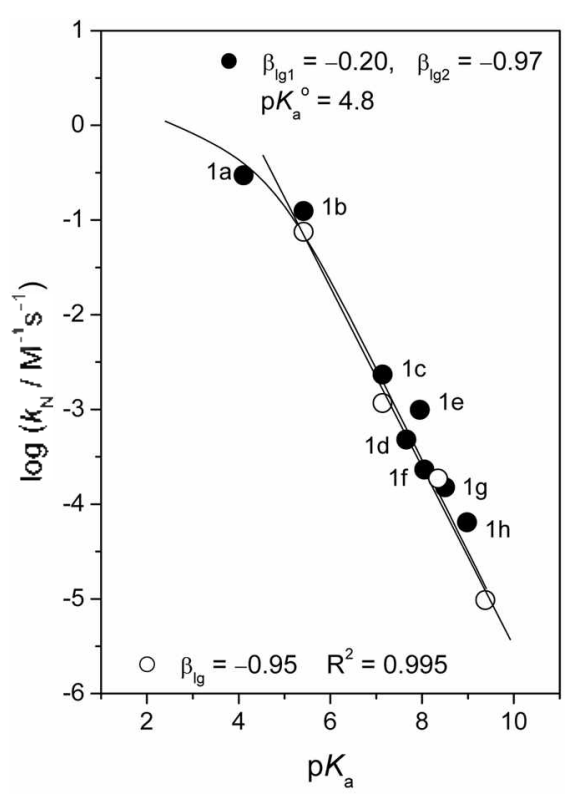

Figure 1. Bronsted-type plots for azidolysis of Y-substituted phenvl benzoates (, $1 \mathbf{a}-\mathbf{h}$ ) and cinnamates $(:)$ at $25.0 \pm 0.1{ }^{\circ} \mathrm{C}$. The identity of the points is given in lable 1 . The data for the azidolysis of aryl cinnamates were taken from ref. 20 .

leaving group (e.g., 1a) have often exhibited a negative deviation from Bronsted-type plot. ${ }^{16,7 a}$ Jencks et al. have attributed such negative deviation to steric hindrance caused by the presence of a $\mathrm{NO}_{2}$ group at the 2-position of the leaving aryloxide. ${ }^{1 \mathrm{l}}$ The effect of steric hindrance has been suggested to be $0.12 \mathrm{log}$ units. Thus. the point for the reaction of $1 \mathrm{a}$ in Figure 1 has been corrected by $0.12 \log$ units. .c

As shown in Figure 1. the Bronsted-type plot for the azidolysis of 1a-h exhibits a downward curvature. The current Bronsted-type plot can be compared with the one reported for azidolysis of $\mathrm{Y}$-substituted phenyl cinnamates $\left(\mathrm{Y}=3.4-\left(\mathrm{NO}_{2}\right)_{2} \text {. 4-NO, 3- } \mathrm{NO}_{2} \text {, and } 4-\mathrm{Cl}\right)^{30}$ Suh et al have reported a linear Bronsted-type plot with $\beta_{\mathrm{g}}=-0.95$ for the reactions of aryl cimnanates with $\mathrm{N}_{3}^{-}$, and concluded that the reactions proceed through a stepwise mechanism with the second step being the RDS on the basis of the magnitude of the $\beta_{\text {lg value. }}{ }^{\text {(i) }}$ The Bronsted-type plot shown in Figure 1 is

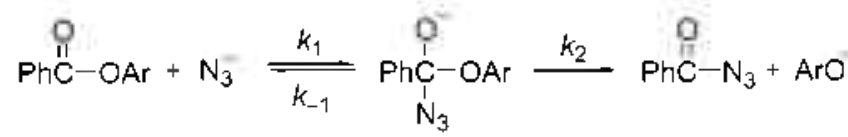

Scheme 1

almost identical to the one reported by Sulh $e t a l$. when the point for the reaction of $1 \mathrm{a}$ is excluded (see the open circles in Figure 1). Thus, one can suggest that the current azidolysis proceeds through a stepwise mechanism as shown in Scheme 1 , and a change in the RDS is responsible for the curved Bronsted-type plot.

Hammett Correlations. To examine the above argument, Hammett plots have been constructed using the kinetic data in Table 1. Hanmett correlations with $\sigma^{\text {va }}$ and $\sigma^{-}$constants have often been found to be useful to determine reaction mechanisms, especially to get information on the RDS. ${ }^{15.17}$ For example. one might expect a better Hanmett correlation with $\sigma^{-}$than $\sigma^{*}$ constants if the departure of the leaving group occurs in the RDS. or $\sigma$ constants would result in a better linear correlation than $\sigma^{-}$constants if the leaving group departs after the RDS.

As shown in Figures 2A and 2B. $\sigma$ constants result in only slightly better correlation than $\sigma^{-}$constants (i.e. $\mathrm{R}^{2}=$ 0.979 for $\sigma^{3}$ and $\mathrm{R}^{2}=0.971$ for $\sigma^{-}$constants). Besides. both Hammett plots exhibit highly scattered points. Thus, one cannot obtain any conclusive information on the reaction mechanism from these Hammett plots

Yukawa-Tsuno Correlation. We have recently shown that the dual-parameter Yukawa-Tsuno equation (eq. 1) is highly effective to elucidate ambiguities in the reaction mechanism of benzoyl..${ }^{5}$ sulfonyl-. ${ }^{6}$ and phosplinyl-transfer reactions. ${ }^{7,21}$ Thus. a Yukawa-Tsuno plot has been constructed for the reactions of $\mathbf{1 b}-\mathbf{h}$ with $\mathrm{N}_{3}^{-}$. As shown in Figure 3 , the Yukawa-Tsuno plot exhibits an excellent linear correlation (i.e., $\mathrm{R}^{2}=0.999$ ) with $\rho=2.45$ and $r=0.40$.

$$
\log k^{k^{\prime} / k^{\mathrm{H}}}=\rho\left[\sigma^{\mathrm{H}}+n\left(\sigma^{-}-\sigma^{\circ}\right)\right]
$$

The $r$ value in the Yukawa-Tsuno equation represents the resonance demand of the reaction center or the extent of
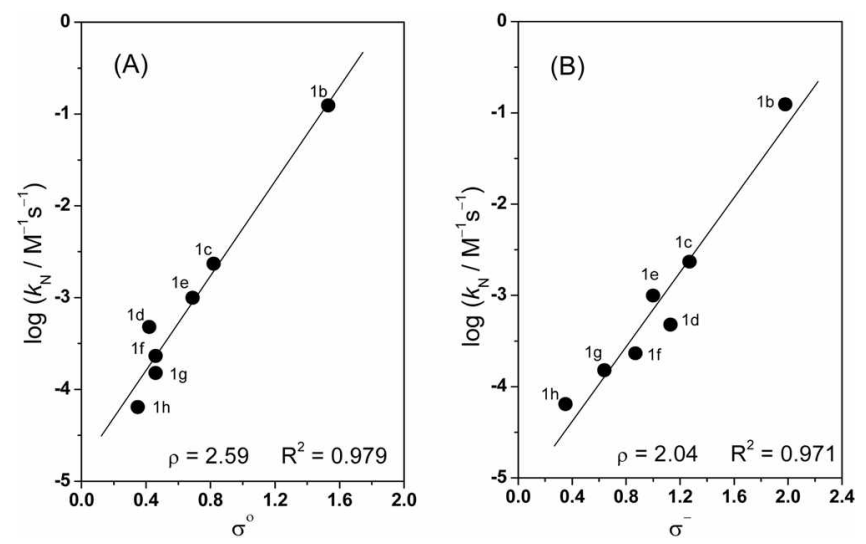

Figure 2. Hammett plots correlated with $\sigma^{\circ}$ (A) and $\sigma^{-}$(B) constants for reactions of Y-substituted phenyl benzoates $(1 \mathrm{~b}-\mathrm{h})$ with $\mathrm{N}_{3}{ }^{-}$in $80 \mathrm{~mol} \% \mathrm{H}_{2} \mathrm{O} / 20 \mathrm{~mol} \% \mathrm{DMSO}$ at $25.0 \pm 0.1^{\circ} \mathrm{C}$. 


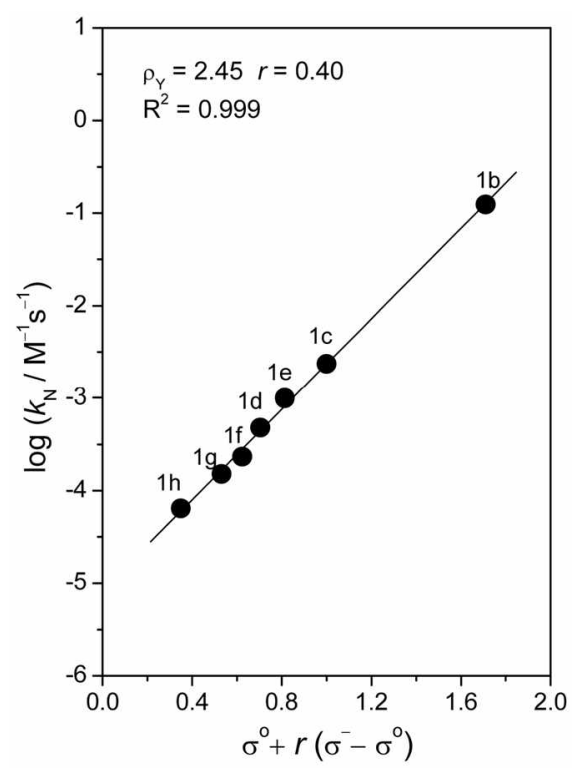

Figure 3. Yukawa-Tsuno plot for reactions of Y-substituted phenyl benzoates (1b-h) with $\mathrm{N}_{3}{ }^{-}$in $80 \mathrm{~mol} \% \mathrm{H}_{2} \mathrm{O} / 20 \mathrm{~mol} \%$ DMSO at $25.0 \pm 0.1^{\circ} \mathrm{C}$.

resonance contribution. ${ }^{2-}$ The fact that $r=0.40$ in the current azidoly sis indicates that a partial negative charge develops on the $\mathrm{O}$ atom of the leaving aryloxide in the rate-deternining transition state. which can be delocalized on the substituent $\mathrm{Y}$ through resonance interaction. Thus. the linear Yukawa-Tsuno plot with $r=0.40$ indicates clearly that departure of the leaving group occurs in the RDS for the azidolysis of $\mathbf{1 b}-\mathbf{h}$<smiles>[N-]C(=O)C(=O)OC(=O)c1ccccc1</smiles>

$\mathrm{TS}_{1}$<smiles>NC(=O)c1ccccc1</smiles>

$\mathrm{TS}_{2}$
One can suggest two transition-state (TS) structures. TS and $\mathrm{TS}_{\mathrm{3}} . \mathrm{TS}_{\mathrm{l}}$ represents the TS for a concerted mechanisn. in which the $\mathrm{N}-\mathrm{C}$ bond formation and C-OAr bond rupture occur at the same time. TS corresponds to the TS for a stepwise mechanism. where the N-C bond formation is complete and the leaving group departs partially in the TS of the RDS. Departure of the leaving group is advanced partially for both $\mathrm{TS}_{3}$ and $\mathrm{TS}_{\mathrm{S}}$. However. the $\rho$ value of 2.45 in Figure 3 is typical for reactions which proceed through rate-determining breakdown of an intermediate. Thus. one can suggest that the azidolysis of $\mathbf{1 b}$-h proceeds through TS.

Dissection of $k_{\kappa}$ into $k_{1}$ and $k_{2} / k_{-1}$ Ratio. The nonlinear Bronsted-type plot shown in Figure $I$ can be analyzed using a semiempirical equation (eq. 2). ${ }^{.3}$ in which $\beta_{\mathrm{gg}}$ and $\beta_{\mathrm{lg}}$ represent the slope of the Bronsted-type plot at the low and the high $\mathrm{p} K_{\mathrm{a}}$ region. respectively. The curvature center of the curved Bronsted-type plot has been defined as $\mathrm{p} K_{a}^{\circ}$ (t.e. the $\mathrm{p} K_{a}$ where the RDS changes). ${ }^{2+}$ The $k_{\mathrm{N}}$ refers the $k_{\mathrm{v}}$ value at $\mathrm{p} K_{\mathrm{i}}{ }^{\circ}$. The parameters determined from the fitting of eq. 2 to the experimental points are $\beta_{\mathrm{lg}]}=-0.20 . \beta_{\text {lg: }}=-0.97$. and $\mathrm{p} K_{\mathrm{a}}{ }^{\circ}=4.8$ for the reactions of $1 \mathrm{a}-\mathrm{h}$ with $\mathrm{N}_{3}{ }^{-}$.

$$
\begin{aligned}
& \log \left(k_{\mathrm{N}} / k_{\mathrm{\Lambda}}{ }^{\circ}\right)=\beta_{\mathrm{g}]}\left(\mathrm{p} K_{4}-\mathrm{p} K_{a}^{\circ}\right)-\log [(1+\alpha) / 2] . \\
& \text { where } \log \alpha=\left(\beta_{\mathrm{lg} 1}-\beta_{\text {lg } 2}\right)\left(\mathrm{p} K_{\mathrm{a}}-\mathrm{p} K_{\mathrm{a}}^{\mathrm{O}}\right)
\end{aligned}
$$

The $\mathrm{p} K_{\mathrm{cl}}$ of 4.8 is practically identical to the $\mathrm{p} K_{\mathrm{cl}}$ of the conjugate acid of $\mathrm{N}_{3}^{-}(4.73)$. This indicates that the nucleofugality of azide is similar to that of the isobasic aryloxide This is contrasting to the report by Suh et al ${ }^{3}$ They performed azidolysis of aryl cimamates and concluded that azide is a better nucleofige than the ary loxides employed in their study. ${ }^{21}$ Such conclusion was possible since $\mathrm{N}_{3}^{-}$is ca. $0.7 \mathrm{p} K_{\mathrm{a}}$ units less basic than the least basic leaving ary loxide (i.e., 3.4-dinitrophenoxide).

The microscopic rate constants (i.e. $k_{1}$ and $k_{2} / k_{-1}$ ratios) associated with the reactions of $1 \mathbf{a}-\mathbf{h}$ with $\mathrm{N}_{3}^{-}$have been calculated using the method reported by Castro et al ${ }^{2-4}$ on the assumption that the reactions proceed through a stepwise mechanism as shown in Scheme 1. The rate equation and the apparent second-order rate constant (iv) for the current reactions can be expressed as eqs. (3) and (4). Eq. (4) can be simplified to eq. (5) or (6). Then. $\beta_{\text {[g] }}$ and $\beta_{\text {[g: }}$ can be expressed as eqs. (7) and (8), respectively.

$$
\begin{aligned}
& \text { Rate }=k_{\mathrm{K}}[\text { substrate }]\left[\mathrm{N}_{2}{ }^{-}\right] \\
& k_{\mathrm{N}}=k_{1} k_{2} /\left(k_{-1}+k_{2}\right) \\
& k_{\mathrm{N}}=k_{1} k_{2} / k_{-1} \text {, when } k_{2} \ll k_{-1} \\
& k_{\mathrm{N}}=k_{1} \text {, when } k_{2}>k_{-1} \\
& \beta_{\text {lg] }}=\mathrm{d}\left(\log k_{1}\right) / \mathrm{d}\left(\mathrm{p} K_{4}\right) \\
& \beta_{\mathrm{gg} 2}=\mathrm{d}\left(\log k_{1} k_{2} / k_{-1}\right) / \mathrm{d}\left(\mathrm{p} K_{a}\right) \\
& =\beta_{\text {lgl }}+\mathrm{d}\left(\log k_{\mathrm{V}} / k_{-1}\right) / \mathrm{d}\left(\mathrm{p} K_{a}\right)
\end{aligned}
$$

Eq. (8) can be rearranged as eq. (9). Integral of eq. (9) from $\mathrm{p} K_{a}{ }^{\circ}$ results in eq. (10). Since $i_{2}=k_{-1}$ at $\mathrm{p} K_{a}{ }^{\circ}$. the term $\left(\log k_{2} / k_{-1}\right)_{p K^{\circ}}{ }^{\circ}$ is zero. Therefore. one can calculate the $k_{2} / k_{-1}$ ratios for the reactions of $1 \mathrm{a}-\mathrm{h}$ from eq. (10) using $\mathrm{p} K_{\mathrm{a}}{ }^{\circ}=$ 4.8, $\beta_{\text {lgl }}=-0.20$ and $\beta_{\text {lg }}=-0.97$.

$$
\begin{aligned}
& \beta_{\mathrm{gg} 2}-\beta_{\lg 1}=\mathrm{d}\left(\log k_{y} / k_{-1}\right) / \mathrm{d}\left(\mathrm{p} K_{4}\right) \\
& \left(\log k_{\mathrm{z}} / k_{-1}\right)_{\mathrm{pKa}}=\left(\beta_{\mathrm{gg} 2}-\beta_{\mathrm{gg}}\right)\left(\mathrm{p} K_{\mathrm{a}}-\mathrm{p} K_{\mathrm{a}}^{\mathrm{o}}\right)
\end{aligned}
$$

The $k_{1}$ values have been determined from eq. (11) using the $k_{\mathrm{N}}$ values in Table $l$ and the $k_{y} / k_{-1}$ ratios calculated above. The $k_{1}$ and $k_{3} / k_{-1}$ ratios obtained in this way are summarized in Table $l$ and illustrated graphically in Figure 4.

$$
k_{\mathrm{N}}=k_{1} k_{2} /\left(k_{-1}+k_{2}\right)=k_{1} /\left(k_{-1} / k_{2}+1\right)
$$

Table 1 shows that $k_{2} / k_{-1}>1$ for the reaction of 1 a but $k_{2} / k_{-1}<1$ for the reactions of $\mathbf{1 b}-\mathbf{h}$. This result is consistent with the preceding proposal that the acidolysis of $\mathbf{1} \mathbf{a}-\mathbf{h}$ proceeds through a stepwise mechanism with a change in the RDS. i.e. the RDS is breakdown of the addition intermediate for the azidolysis of $\mathbf{1 b}$-h. but its formation for the 


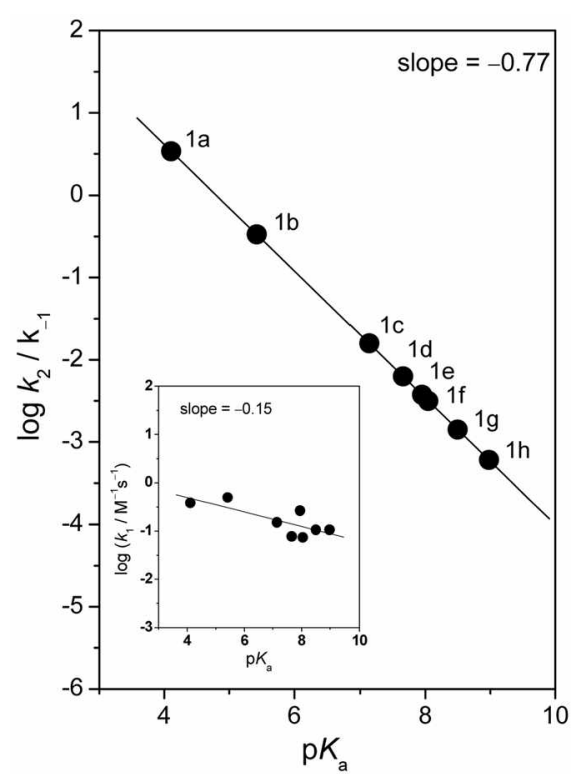

Figure 4. Plots of $\log k_{2} / k_{-1} v s \mathrm{p} K_{\mathrm{a}}$ (and $\log k_{1} v s \mathrm{p} K_{\mathrm{i}}$, inset) for azidolysis of Y-substituted phenyl benzoates (1) $\mathbf{a}-\mathbf{h})$ in $80 \mathrm{~mol} \%$ $\mathrm{H}_{2} \mathrm{O} / 20 \mathrm{~mol} \%$ DMSO at $25.0 \pm 0.1{ }^{\circ} \mathrm{C}$.

\section{reaction of $1 \mathrm{a}$.}

As shown in the inset of Figure 4, the Bronsted-type plot for the $k_{1}$ values results in a poor correlation with $\beta_{\text {lg] }}=$ -0.15 . indicating that the effect of leaving group basicity on $k_{1}$ is insignificant for the current azidolysis. On the contrary. one might expect that the effect of leaving group basicity is significant for the $k_{2} / k_{-1}$ ratio, since $k_{2}$ would be strongly dependent on the leaving group basicity while $k_{-1}$ for $\mathrm{N}_{3}^{-}$ion would remain nearly constant. In fact. as shown in Figure 4. the plot of $\log k / k_{-1} w \mathrm{p} K_{\mathrm{u}}$ results in a large negative slope $(-0.77)$. Thus. the microscopic rate constants are also consistent with the proposal that the current azidolysis proceeds through a stepwise mechanism with a change in the RDS

\section{Conclusions}

The current study has allowed us to conclude the following: (1) The Bronsted-type plot for the azidolysis of 1a-h exhibits a downward curvature. i.e. $\beta_{\mathrm{lg} 1}=-0.20$ and $\beta_{\mathrm{g} 2}=$ -0.97. (2) The Hammett plots conrelated with $\sigma^{\circ}$ or $\sigma^{-}$ constants for the reactions of $\mathbf{1 b}$-h do not give any conclusive information on the reaction mechanism. since both plots show highly scattered points. (3) The corresponding YukawaTsuno plot results in excellent linearity with $\rho=2.45$ and $r=$ 0.40 , indicating that the leaving group departure occurs in the RDS. (4) The current azidolysis proceeds through a stepwise mechanism with a change in the RDS. (5) The microscopic rate constants ( $k_{1}$ and $k_{-} / k_{-1}$ ratio) calculated are consistent $w$ ith the proposed mechanism.

\section{Experimental Section}

Materials. Y-Substituted phenyl benzoates (1a-h) were readily prepared as reported previously ${ }^{19}$ from the reactions of Y-substituted phenol with benzoyl chloride under the presence of trietlyy lamine in anlyydrous ether and purified by column chromatography. The purity was checked by their mp's and spectral data such as ${ }^{1} \mathrm{H}$ NMR and IR spectra.

Kinetics. The kinetic study was performed with a Scinco S-3100 Model UV-vis spectrophotometer equipped with a constant temperature circulating bath. The reactions were followed by monitoring the appearance of Y-substituted phenoxide. Due to the low solubility of the substrates in pure water. aqueous DMSO ( $80 \mathrm{~mol} \mathrm{\%} \mathrm{H}_{2} \mathrm{O} / 20 \mathrm{~mol} \%$ DMSO) was used as the reaction medium. Doubly glass distilled water was further boiled and cooled under nitrogen just before use

All the reactions were carried out under pseudo-first-order conditions in the presence of excess azide ion. Typically. the reaction was initiated by adding $5 \mu \mathrm{L}$ of a $0.01 \mathrm{M}$ of substrate solution in MeCN by a $10 \mu \mathrm{L}$ gastight syringe to a $10 \mathrm{~mm}$ quarts UV cell containing $2.50 \mathrm{~mL}$ of the thermostated reaction mixture made up of solvent and an aliquot of the $\mathrm{NaN}_{3}$ stock solution. The stock solution of $\mathrm{NaN}_{3}$ was prepared in $0.1 \mathrm{M}$ trietlyyl amine buffer solution $(\mathrm{pH}=$ 10.72).

Products Analysis. Y-Substituted phenoxides (and/or the conjugate acids) were liberated quantitatively and identified as one of the reaction products by comparison of the UV-vis spectra after the completion of the reactions with those of the authentic sample under the same reaction conditions.

Acknowledgments. This work was supported by a grant from Korea Research Foundation (KRF-2005-015-C00256). E. H. Kim is also grateful for the BK 21 scholarship.

\section{References}

1. (a) Jencks, W. P. Catalysis in Chemisty and Enzymology: MoGraw-Hill: New York. 1969: pp 480-483. (b) Jencks. W. P: Gilchrist, M $J$. Am. Chem. Soc. $1968,90,2622-2637$. (c) Gresser, M. I.: Jenchs. W. P. J. Am. Chent Soc 1977. 99. 6963-6970. (d) Bruice. T. C.: Fite. T. H.: Bruno. J. J.: Brandont. N. E. Biochentisty 1962. 1.7-12. (e) Kirsch. I. F.: Clewell. W.: Simon. A. J. Org. Chem. 1968, 33. 127-132.

2. (a) Baxter, N. J.: Rigoreau. L. J. M.: Laws, A. P. Page. M. I. d. Am. Chem. Soc 2000, 122. 3375-3385. (b) Zhong. M.: Brauman. J. 1. J. Am. Chent Soc. 1999. 121.2508-2515.

3. (a) Castro. E. A. Chem. Rev 1999. 99. 3505-3524 (b) Castro. E. A. J. Org. Chem. 2005. 70. 8088-8092. (c) Castro. E. A. J. Org. Chem 2003, 68.5930-5935. (d) Castro. E. A.J. Org. Chem. 2003. 68. 3608-3613. (e) Castro. E. A. J. Org. Chem. 2002. 67,89118916. (f) Castro, E. A. J. Org. Chem 2001, 66. 6000-6001.

4. (a) Sung. D. D.: Koo. 1. S.: Yang. K.: Lee. 1. Chem. Phys. Lett. 2006. 126 . 280-284. (b) Sung. D. D.: Koo. I. S.: Yang. K.: Lee. I. Chent Phys. Lett 2006. $+32.426-430$. (c) Ol. H. K.: Oh. J. Y: Sung. D. D.; Lee. I. J. Org. Chem 2005. 70. 5624-5629. (d) Park. Y. H.: Lee, O. S.; Koo. I. S.: Yang, K, Lee. I. Bull Koman Chem. Soc. 2006, 27, 1865-1868.

5. (a) Um. I. H.: Park. Y. M.: Fujio. M.: Mishima. M.: Tsuno. Y. J. Org. Chent 2007. 72.4816-4821. (b) Unt. I. H:: Kim. E. Y.: Park. H. K.: Teon. S. E. J. Org Chent 2006. 7l. 2302-2306. (c) Um. I. H: Jeon, S. E.: Seok. J. A. Chem. Eur J. 2006. 12, 1237-1243. (d) Um. I. H.: Kim, K. H.; Park, H. R; Mizue, F; Yuho, J. J. Org. Chem 2004, 69, 3937-3942. (e) Um, I. H; Akhtar, K; Park, Y 
M.: Khan. S. B. Bull. Korean Chent. Soc. 2007. 28. 1353-1357. (t) Um. I. H.: Chun. S. M.: Akhtar. K. Bull. Korean Chem. So. 2007. $28.220-224$.

6. (a) Unn. I. H.: Hong J. Y.: Seok. I. A. J. Ong. Chem 2005. 70. 1438-1444. (b) Um, I. H: Chun. S. M.: Chae. O. M. Fujio, M: Tsuno. Y. J. Org. Chem. 2004, 69. 3166-3172. (c) Um. I. H: Hong. J. Y.: Kim. J. J.: Chae, O. M.: Bae. S. K. J. Org. Chent 2003. $68.5180-5185$

7. (a) Un. I. H.: Akhtar. K.: Shin. Y. S.: Han. J. Y. J. Org. Chem. 2007, 72. 3823-3829. (b) Um. I. H. Shin. Y. S: Han. J. Y: Mishima, M. J. Org Chem, 2006, 71, 7715-7720.

8. (a) Buncel. E.: Albright. K. G.: Onyido. I. Org. Biomol. Chem. 2005. 3. 1468-1475. (b) Buncel. E.: Albright. K. G. Onyido. I. Org. Bionol. Chem 2004. 2.601-610. (c) Nagelkerke. R: Thatcher. G. R. J.: Buncel. E. Org. Bionol Chem. 2003. I. 163167. (d) Buncel. E.: Nagelkerke, R: Thatcher, G. R. I. Cam. J. Chem. 2003, 81. 53-63

9. (a) Williams, A . Acc. Chem. Res. 1989. 22, 387-392. (b) Ba-Saif. S.: Luthra. A. K. Williams. A. J. Am. Chem. Soc. 1987. 109. 6362-6368. (c) Bourne. N.: Chrystiuk. E.: Davis. A. M.: Williams. A. J. Ant Chem. Soc. 1988. 110. 1890-1895. (d) Deacon. T. C.: Farra, R: Sikkel. B. J.: Willians. A. J. Am. Ghem. Soc. 1978, 100 . 2625-2534. (e) Williams, A; Naylor, I. J. Chem. Soc. B 1971. $1967-1972$

10. Stefanidis. D.: Cho. S.: Dhe-Paganon. S.: Jencks. W. P. J. Am. Chem. Soc. 1993. 115. 1650-1656

11. (a) Andres. G. O.: Granados. A. M.: Rossi. R. H. J. Org. Chent. 2001, 66, 7653-7657. (b) Fernandez, M. A.: Rossi, R. H. J. Org. Chem. 1999, 64. 6000-6004.

12. (a) Castro, E. A: Angel, M.: Arellano. D: Santos, J. G. J. Org. Chem. 2001. 66.6571-6575. (b) Castro. E. A.: Pavez. P. Santos. J. G.J. Org Chem 2001. 66.3129-3132. (c) Castro. E. A.: Pavez. P: Santos. J. G. J. Org Chem. 1999. 64. 2310-2313.

13. (a) Cleland. W. W. Hengge. A. C. Chem. Rev, 2006. 106. 3252 3278. (b) Hengge A. C. Ad Pln's. Org. Chem 2005. 40. 49-108. (c) Catrina, I.: OBrien. P. I. Purcell, J.: Nikolic-Hughes. I.:
Zalatan. T. G.: Hengge. A. C.: Herschlag. D. J. Am. Chem. Soc 2007. 129. 5760-5765. (d) Hengge. A. C.: Onyido. I. Cum Org. Chent 2005. 9.61-74. (e) Onvido. I.: Swierzek. K.: Purcell. J.: Hengge. A. C. J. Am. Chem Soc. 2005, 127.7703-7711.

14. (a) Guthrie. J. P. J. Am. Chem. Soc 1996, 118. 12878-12885, (b) Guthrie, J. P. J. Am. Chem. Soc. 1991. 113, 3941-3949.

15. (a) Um. I. H.: Hwang. S. J.: Buncel. E. J. Org. Chem. 2006. 71. 915-920. (b) Buncel. E.: Um. I. H.: Hoz. S. J. Ant Chent. Soc. 1989. H1. $971-975$.

16. (a) Cook. R. D.; Farah. S.: Ghawi, L.: Itani, A.: Rahil. J. Can. J. Chem. 1986. 64. 1630-1637. (b) Cook. R. D.: Rahhal-Arabi. L. Tetrahedron Lett. 1985. 25, 3147-3150

17. (a) Han. X.: Balakirishnan. V. K.: Buncel. E. Lamgnuir 2007. 23. 6519-6525. (b) Han. X: Balakishnan. V. K: van Loon. G. W: Buncel. E. Lamgnuir 2006. 22. 9009-9017. (c) Cheung. J. C. F: Park. Y. S.: Smith. V. H. van Loon, G:; Buncel, E: Churchill. D. Can. J. Chem. 2006. 84. 926. (d) Churchill. D.: Cheung, J. C. F: Park. Y. S.; Smith. V. H.: van Loon, G.; Buncel. E. Cam. J. Chem 2006. 84. 702-708. (e) Balakrishnan. V. K.: Buncel. E.: van Loon. G. W. Emiron. Sci. Technol. 2005. 39.5824-5830. (f) Balakrishnan. V. K.: Han. X.: van Loon. G. W.: Dust. J. M.: Toullec. J.: Buncel. E. Langmiv 2004. 20,6586-6593.

18. Um. I. H.: Kim, M. J.: Lee, H. W. Chem. Commm. 2000, 2165 2166.

19. Unn. I. H.: Lee. J. Y: Fujio. M.: Tsun1o. Y. Org. Bionol. Chent. 2006. +. 2979-2985

20. Sulh. T.: Lee. B. H. J. Org. Chem. $1980 .+5.3103-3107$.

21. Um. I. H.; Park, J. E.: Shin. Y. H. Org. Biomol. Chem. 2007, 5. $3539-3543$

22. (a) Tsuno, Y: Fujio. M. Adv Phws. Org. Chem. 1999. 32, 267-385 (b) Tsuno. Y.: Fujio. M. Chent. Soc. Rev 1996. 25. 129-139. (c) Yukawa. Y.: Tsuno. Y. Bull. Chem. Soc. Jpn. 1959.32.965-970.

23. (a) Castro. E. A.: Moodie. R. B. J. Chem. Soc. Chent Contmum 1973. 828-829. (b) Gresser, M. J.; Jencks. W. P. J. Am. Chem. Soc $1977.99,6963-6970$.

24. Castro, E. A.; Ureta, C. J. Org. Chem. 1989. 54, 2153-2157. 